This is a peer-reviewed, accepted author manuscript of the following research article: Nakamura, J., \& Hazin, F. (2020). Assessing the Brazilian federal fisheries law and policy in light of the Voluntary Guidelines for Securing Sustainable Small-scale Fisheries. Marine Policy, 113 ,

[103798]. https://doi.org/10.1016/j.marpol.2019.103798

\title{
Assessing the Brazilian Federal Fisheries Law and Policy in light of The Voluntary Guidelines for Securing Sustainable Small-scale Fisheries
}

\section{Introduction}

Inland and marine coastal small-scale fisheries (SSF) are millenary traditional fishing practices used for subsistence and commercial purposes in formal and informal markets around the world. It is a prominent fisheries sector particularly in developing countries, where SSF activities play a fundamental role as a source of food, nutrition, jobs, income, culture, values and leisure to millions of people. Yet, this sector has been often dwarfed from government priorities, excluded from financial subsidies and left to poor, marginalized and vulnerable conditions in societies [1-4]. A lot has been written on SSF issues and the scientific literature keeps on rising [1-10]. Only in the last three decades, however, International Fisheries Law i.e. the field of public international law mainly concerned with the use, management and conservation of marine fishery resources, has been dedicating rules particularly addressed to this sector, but still in a very limited way. Few provisions related to access rights of small-scale fishers to fishery resources and fishing grounds, protection of their rights to secure and just livelihood and/or which take into account the interests of SSF in fisheries management are found in international instruments adopted in 1995, notably the so-called United Nations (UN) Fish Stocks Agreement [11] (Articles 5(i) and 24(2)(b)), the UN Food and Agriculture Organization (FAO)'s Code of Conduct for Responsible Fisheries [12] (Articles 6.18, 7.2.2(c), 7.6.6, 8.4.8, 8.11.3, 9.4.2, 10.1.3) and the Kyoto Declaration [13] (Paras 2 and 17).

Further guidance led by the FAO on fisheries related issues, including the technical guidelines on the ecosystem approach to fisheries (EAF) [14], the Voluntary Guidelines on the Progressive Realization of the Right to Adequate Food [15], the Voluntary Guidelines on the Responsible Governance of Tenure of land, fisheries and forests [18] and related publications [16, 17, 19], have highlighted the importance of SSF as a source of food, income, leisure, culture and their contributions to livelihoods and sustainability [14-19]. This initiative has pushed forward the momentum for technical consultations and negotiations carried out by governments, academia, civil society, small-scale fishers and other relevant stakeholders, more intensely with the turn of the century, resulting in the adoption in June 2014 of the Voluntary Guidelines for Securing Sustainable Small-scale Fisheries in the Context of Food Security and Poverty Alleviation (SSF Guidelines) [20, 21].

As an international non-binding legal instrument, the implementation and enforcement of the SSF Guidelines depend on the countries' will and action. Some of these provisions may, to one extent or another, be already in place in previously 
This is a peer-reviewed, accepted author manuscript of the following research article: Nakamura, J., \& Hazin, F. (2020). Assessing the Brazilian federal fisheries law and policy in light of the Voluntary Guidelines for Securing Sustainable Small-scale Fisheries. Marine Policy, 113 ,

[103798]. https://doi.org/10.1016/j.marpol.2019.103798

adopted national fisheries legal and policy frameworks or may have never been addressed by any of such instruments at all. Opportunities remain thus to investigate these national frameworks and identify the needs for future amendments and/or enactments of new legislation and adoption of policies that either comprise relevant issues of the SSF sector or are entirely devoted to them. Upon this background, the present article assesses the legal and policy frameworks of Brazil in an attempt to indicate the currently in-force and main national legislations and policies that are relevant for the implementation of the SSF Guidelines at federal level. This article also feeds into the works carried out to achieve the Sustainable Development Goals (SDGs), mainly SDG 14 for the effective regulation of harvesting and provision of access to small-scale fishers to marine resources and markets [6-8, 22] (Targets 14.4 and 14.b). It also envisions the contribution to other SDGs, based on the association of SSF as key contributors to various SDG goals - including SDG 1 on poverty reduction, SDG 2 on food security, SDG 3 on wellbeing for all, SDG 5 on gender equality and SDG 8 on economic growth and decent work -, as it has been recently made elsewhere [23].

This article is structured in four parts. First, it highlights the important features of the SSF Guidelines as part of contemporary International Fisheries Law. Second, it provides an overview of the Brazil's fisheries sector and governance briefly informing on the institutional arrangements, legal and policy frameworks at federal level. The third part provides an analysis of the Brazilian federal fisheries primary law and policy, highlighting in particular how the SSF sector is covered by that law, the alignment of that law with a human rights-based approach (HRBA) and the EAF, presenting other provisions that are relevant for the SSF sector in that law, and examining other issues that other federal legislations provide for in support of the SSF Guidelines' implementation. The fourth part finally concludes with the main idea to inform legal practitioners and policy-makers in applying the selected federal legislations and policies in an integrated manner as to ensure that the relevant matters of the SSF Guidelines are appropriately addressed and applied in Brazil.

The assessment conducted in part four of this article provides a useful tool that could be applied in other countries that may have a similar legal and institutional framework. There are various ways through which the SSF Guidelines can be implemented [24] and this article is focused on a critical appraisal of the national fisheries primary law and policy in Brazil. This article provides useful insights on the various areas of law and policy that should be considered when implementing the SSF Guidelines, following coherent, coordinated and collaborative approaches that this instrument calls for [20] (Section 10). 


\section{The SSF Guidelines' relevance within the International Fisheries Law context}

International Fisheries Law integrates the broader Law of the Sea regime and may be seen as the field of international law devoted to the "conservation, management and/or development of marine capture fisheries" [25] (p. 3). Atypical to what is usually seen in this traditional law branch - i.e. instruments focused on regulating the access to, use and management of fishery resources globally [26] (p. 56) -, the SSF Guidelines in a rather unique way are centered on a HRBA and follows an EAF. As such, it goes beyond the scope of those fisheries instruments integrating both social and environmental concerns. In addition to responsible fisheries management and development, this instrument addresses a wide range of matters that include gender equality, safety-at-sea, climate change adaptation and resilience, etc. [20]. The soft law or voluntary nature of the SSF Guidelines provides flexibility and allows for the appropriate adaptability, where States opt to align their legal and policy frameworks with the SSF Guidelines' requirements. They can be applied by anyone, not limited to FAO member-States, but also to non-members, non-State actors and any other stakeholder from the private or public sectors [20] (Subsection 2.3).

Another positive feature that makes the SSF Guidelines such an important and original legal source is that it integrates in a single instrument the many relevant SSFrelated issues concerning the SSF sector's recognition, empowerment, and inclusion, as well as improved, adequate and fair protection of small-scale fisher's rights. It provides a unique framework that focuses on all persons, including men, women and children participating in any of the fishing and fishing-related activities. This concern is reflected in the objectives of the SSF Guidelines, which are to be achieved through a HRBA, as well as in the guiding principles that are based on inter alia international human rights standards and in the many human rights-related instruments referred therein [20] (Subsections 1.2, 3.1). In this sense, the SSF Guidelines provide an evolved manner of regulating international fisheries, which recognizes not only the importance of the SSF sector and the people involved in it for the society as a whole, but also emphasizes the special attention they need for sustaining their livelihoods and carrying out their activities under vulnerable and difficult conditions.

An important element of the SSF Guidelines, which is also not often found in traditional international fisheries instruments, is the explicit reference to the EAF [14]. The EAF is considered as an important guiding principle to foster a participatory and integrated way of sustainably using and managing all ecosystems, with due account of coordinated efforts between the SSF sector and other stakeholders [20] 
This is a peer-reviewed, accepted author manuscript of the following research article: Nakamura, J., \& Hazin, F. (2020). Assessing the Brazilian federal fisheries law and policy in light of the Voluntary Guidelines for Securing Sustainable Small-scale Fisheries. Marine Policy, 113 ,

[103798]. https://doi.org/10.1016/j.marpol.2019.103798

(Subsections 1.1(e), 3.1(11), 5.1, 6.1, 7.5, 10.5, 10.7). The EAF is a holistic and inclusive strategy to sustainably manage fisheries. The human component of the EAF is fundamental to SSF as it promotes transparency in management processes and the participation of all relevant stakeholders, including lower level authorities and smallscale fishing communities, in the relevant fisheries-related decision-making process affecting them [19] (pp. 20-21). This element of the EAF pushes forward the shift from rigid centralized administration, which does not involve fishing communities in any of the planning, preparatory and development stages of fisheries management, to more flexible, decentralized approaches that adequately integrate fishers and all relevant stakeholders in such processes, enabling them to be informed, participate in the discussions and contribute with their knowledge, opinions and practical experience.

As anticipated, the SSF Guidelines address a variety of issues to which the SSF may be directly or indirectly related. This broad scope provides a sense of comprehensiveness to the instrument and provides nexus to the different international legal sources that apply to the SSF context. By reference to relevant legally-binding treaties such as the Convention on the Elimination of All Forms of Discrimination Against Women and the UN Framework Convention on Climate Change, [20] (Subsections 3.1(2), 6.12, 6.15, 9.1), it enforces the respective obligations of States parties to those treaties connecting their applicability to the SSF sector. The references to non-binding legal instruments such as the FAO Code of Conduct for Responsible Fisheries and the 'Future We Want' declaration [20] (Subsections 1.1(c), $3.1,5.8)$, in turn, strengthen the requirements and recommendations of such instruments, which have gone thorough longer periods of implementation and consolidation, bringing their observance within the SSF context. In many times throughout the text of the SSF Guidelines, those references recall the international commitments and standards for States to comply with and observe on matters related, for instance, to gender, indigenous people, children and climate change [20] (Subsections 3.1(2)(6), 6.15 and 9.1). In doing so, they contribute to enforcing those instruments while ensuring that they are taken into account with respect to SSF matters.

All the foreseen elements of the SSF Guidelines evince their particular role in International Fisheries Law in bringing a holistic and innovative framework that gathers, in a single legal piece, the main global concerns that are relevant for the SSF sector. As such, the SSF Guidelines conciliate the protection of human rights of the people involved in the SSF sector, the need to conserve ecosystems and fishery resources while promoting the social, economic and environmental sustainability in fisheries development. These features construe an important bridge between the domain of International Fisheries Law and the environmental, human rights, trade, labour and other relevant international law fields. In the following section, another 
This is a peer-reviewed, accepted author manuscript of the following research article: Nakamura, J., \& Hazin, F. (2020). Assessing the Brazilian federal fisheries law and policy in light of the Voluntary Guidelines for Securing Sustainable Small-scale Fisheries. Marine Policy, 113 ,

[103798]. https://doi.org/10.1016/j.marpol.2019.103798

linkage will be made, but this time through the examination of those matters in the Brazilian federal legal framework. The importance in assessing how the SSF Guidelines are reflected at national level is that it creates opportunity to find different ways of how a country may regulate to some extent the issues that are relevant for SSF, potentially strengthening the SSF Guidelines' implementation. The manner through which fishery resources in particular are used and managed by the millions of fishers, mostly small-scale fishers, across Brazil's inland and marine waters, is pivotal to ensure fisheries long-term sustainability at national and international levels.

\section{An overview of the Brazilian fisheries sector and governance}

Brazil is a sovereign republic with a vast marine coastline of around $7400 \mathrm{~km}$, over 3.5 million square kilometers across its' 200 nautical miles of exclusive economic zone (EEZ), 8.2 billion cubic meters of water distributed in rivers, lakes, dams and reservoirs, and approximately $13 \%$ of the freshwater available in the world [27]. With abundant water resources and favorable climate conditions, capture fisheries including SSF operate in all five regions of the country - North, Northeast, CentralEast, South and Southeast - playing a significant role in the national socio-economic context, and contributing to the country international trade. Fisheries activities contribute to the nation's income generating $\mathrm{R} \$ 5$ billion in gross national product (GNP) and approximately 3.5 million of direct and indirect jobs [28]. The fisheries and aquaculture sectors are also essential sources for the country's food security and are embedded in traditional cultural practices, integrating the daily routine of millions of Brazilians, who, as women and men fishers, are involved in fishing and aquaculture. Most of the national fisheries production derives from marine capture and inland aquaculture, with most of the production coming from the Northeast region, where the vast majority of the production comes from the artisanal fisheries [29].

Throughout Brazil's history, both inland and marine fishing have been practiced in great part by vulnerable groups, including indigenous peoples and tribes, since precolonial times, and slaves, during the colonial period [30]. It continues to be an activity carried out by most of the Brazilian fishers' population, who fish for subsistence and/or local markets. A recent study showed that in 2013, there were 440,266 professional and subsistence artisanal fishers in Brazil (Brazilian SSF sector), which correspond to the vast majority of the fisheries workforce $(90,3 \%)$, with a much lower number 47,884 of fishers being engaged in the industrial fisheries sector $(9,7 \%)$ [31]. The vulnerability, marginalization and poor conditions of the SSF sector, which are generally seen around the developing world, are likewise dominant in the Brazilian SSF sector. The expectation for improvements, at least in respect of gaining more attention from the government in policies, has not been sufficiently met yet. Even with the election of the Workers' Party in 2003, and during the period of its' first and second governance, the 
This is a peer-reviewed, accepted author manuscript of the following research article: Nakamura, J., \& Hazin, F. (2020). Assessing the Brazilian federal fisheries law and policy in light of the Voluntary Guidelines for Securing Sustainable Small-scale Fisheries. Marine Policy, 113 ,

[103798]. https://doi.org/10.1016/j.marpol.2019.103798

public policies have not appropriately addressed the SSF sector [32], in spite of some improvements, such as the creation of national forums to discuss SSF social issues [33]. Policies have been sought to focus on limited aspects, including cost reduction in SSF activities and greatening their revenues [32] rather than broadly covering all social, environmental and economic issues that the SSF faces in the country [33].

\subsection{Brazilian federal institutional arrangements for fisheries}

Institutional arrangements to manage the fisheries and aquaculture sector in Brazil are complex. Each one of the entities forming its political administrative organization - i.e. the Federal Union, the 27 federal units comprising 26 states and the Federal District, and over 5,570 municipalities [34] - have the autonomous power to develop, organize and set up their own administrative institutions and policies for those sectors, according to the 1988 Brazilian Federal Constitution [35] (Articles 1 and 18). Consequently, there is a large number of institutions devoted or related to fisheries and aquaculture within the federal, state and municipal administrative structures. At national level, the responsibility for the governance of fisheries and aquaculture have passed in the past ninety years through several changes, which can be visualized in Figure 1 below.

The mandate to manage Brazilian fisheries moved from the Ministry of Agriculture (1933-1962), to the Superintendence for the Development of Fisheries (1962-1989), and then to the Ministry of the Environment (1989-1998). From 1998 until the end of 2018, the mandate was shared between the Ministry of the Environment and another institution: the Ministry of Agriculture, Livestock and Food Supply (MALFS) (19982003), the Special Secretary of Aquaculture and Fisheries (2003-2009), the Ministry of Fisheries and Aquaculture (2009-2016), the MALFS (2016-2017) again, the Ministry of Industry, Foreign Trade and Services (2017-2018), and the Special Secretariat of Aquaculture and Fisheries (2018). In 2019, after 20 years of shared mandate, the institutional responsibility for the management of the Brazilian fisheries sector was again unified in a single institution i.e. the Secretary of Aquaculture and Fisheries, under MALFS [32, 36, 37], back to the situation that prevailed until 1962.

\section{Figure 1 here}

These frequent institutional shifts and successive changes of mandates weakened the governance of the fisheries sector in Brazil, with serious repercussions at the international level, though the country has been active in certain regional fisheries management organizations [e.g. 38]. A problem in Brazil has been the failure to submit 
This is a peer-reviewed, accepted author manuscript of the following research article: Nakamura, J., \& Hazin, F. (2020). Assessing the Brazilian federal fisheries law and policy in light of the Voluntary Guidelines for Securing Sustainable Small-scale Fisheries. Marine Policy, 113 ,

[103798]. https://doi.org/10.1016/j.marpol.2019.103798

official fisheries statistics to the FAO since 2014, despite Brazil being by large the main inland water fish producer in South America and one of the major aquaculture producers [39] (pp. 16; 28-19). In addition to the institutional fragility, almost all Brazilian fishers work in the artisanal sector, as highlighted previously [31, 40]. As in other developing countries, the Brazilian SSF sector comprises a low-income workforce that operates in vulnerable conditions, within a rather limited geographical range, fishing most of the time near shore, either disembarked or using small vessels, modest fishing gears and equipment [1-4]. The SSF has historically been kept away from decision-making processes, lacking visibility and attention from the government and being generally marginalized from the society as a whole [3] (pp. 336-337), a reality also in Brazilian SSF. Some states' Constitutions (e.g. Amazonas, Amapá, Ceará, Espírito Santo, Maranhão, Pará, Rio de Janeiro, Rio Grande do Norte, Santa Catarina and Tocantins), however, provides for the mandates of fisheries and aquaculture institutions, which cover the responsibility to develop fisheries policy taking into account SSF issues [41].

While the lack of strong and stable governmental institutional arrangements for fisheries management have kept, if not worsen, the persisting problems faced by the SSF in the country, such deficiencies have brought opportunities for self-oriented governance. These include the capacity of SSF governance being conducted by nonState actors as well and within non-legally or non-officially recognized structures. In Brazil, SSF communities, fishing associations, non-governmental organizations and civil society organizations participate in the management of fisheries in various forms, including through co-management and community-based management schemes [42]. Although the State provides the main legal framework, it is not possible to solely rely on the State in the face of its own organizational difficulties. Legal pluralism - as an analytical transdisciplinary perspective, combining different legal systems and capacities of multiple actors to collectively govern a given situation [43, 44] -, can thus occur in this context. For example, an empirical study conducted with a traditional SSF community in the Northeast Brazil has demonstrated how legal pluralism, through the recognition and application of customary local law by the community, has positively contributed to resolve socio-environmental conflicts and ensure tacit compliance with these local rules [45].

\subsection{Brazilian federal legal and policy framework}

Brazil has a continental dimension with social, cultural, economic and legal characteristics that are greatly diversified by regions, states and municipalities. The Federal Union, representing the national government, is the competent authority to establish the general rules for fisheries [35] (Article 24, IV, §1). Each of the 26 states as well as the Federal District, however, have the authority to supplement such rules 
This is a peer-reviewed, accepted author manuscript of the following research article: Nakamura, J., \& Hazin, F. (2020). Assessing the Brazilian federal fisheries law and policy in light of the Voluntary Guidelines for Securing Sustainable Small-scale Fisheries. Marine Policy, 113 ,

[103798]. https://doi.org/10.1016/j.marpol.2019.103798

and may exercise full competency to legislate in matters of their interest that are not addressed by the general legal framework [35] (Article 24, §§2-4). The numerous municipalities, in turn, may also legislate on those issues that affect their local interests provided that the municipal legal instruments are not contrary to the federal and states legislations [35] (Article 30(I)(II)). As a result, legislations enacted by all these political entities, the policies adopted, and the executive orders issued by their ministries and agencies are not only sheer in number, but quite cumbersome and, in many cases, conflicting or redundant. States and municipalities' legal frameworks, nevertheless, are important in providing detailed regulation on SSF, especially due to this sector's dynamic and peculiar demands, but the main general framework is still the one setting the fundamental requirements for SSF, to be followed by all sub-national entities.

Differently from the institutional arrangements, the Brazilian federal legal framework governing fisheries and aquaculture has gone through much less changes in the past century. For more than forty years (1967-2009), the so-called Fisheries Code i.e. the Federal Decree-Law No. 221/1967 provided the national primary legislation regulating fisheries, including SSF and aquaculture. This legislation was elaborated at a time when the federal government was much more focused on promoting the development and industrialization of Brazilian fisheries, and much less concerned with the social development, rights and safeguards of fishers and fishing communities [32, 46]. A significant change occurred with the enactment of the Federal Law No. 11,959/2009, which almost entirely substituted the former code, providing an improved legal framework for the sustainability in fisheries. This legislation functions as the national fisheries and aquaculture both legal and policy frameworks (NFALP), providing the National Policy for the Sustainable Development of Aquaculture and Fisheries, as well as regulating at federal level all fishing activities in the country [47].

\section{Assessing the Brazilian federal legal and policy frameworks for SSF}

\subsection{Preliminary considerations and methodology used}

In assessing how the currently in-force federal legal and policy frameworks support the SSF Guidelines, this article considered as a fundamental basis the NFALP as it is the main national legislation/policy specifically devoted to fisheries and aquaculture in Brazil. The NFALP is structured in seven chapters and 38 articles, setting out the national standards that any other related federal, state and municipal law, regulation and policy formulation must observe. In the present analysis, a preliminary assessment was conducted in a three-step process. First, the main provisions of the NFALP, which are relevant for the SSF sector in particular were identified. Second, each of the selected NFALP provisions was cross-examined with 
This is a peer-reviewed, accepted author manuscript of the following research article: Nakamura, J., \& Hazin, F. (2020). Assessing the Brazilian federal fisheries law and policy in light of the Voluntary Guidelines for Securing Sustainable Small-scale Fisheries. Marine Policy, 113 ,

[103798]. https://doi.org/10.1016/j.marpol.2019.103798

the correspondent SSF Guidelines' sections or subsections. From this evaluation it was possible to depict the differences between the requirements of the NFALP and those of the SSF Guidelines. For instance, the objective of the NFALP of promoting the sustainable development of fisheries and aquaculture [47] (Article 1(I)) does not clearly consider the right to adequate and nutritious food nor the responsible governance of tenure as provided by the SSF Guidelines [20] (Subsections 1.1(a) and 5.2). Finally, this closer look at the terms used in the NFALP in each of its selected provisions further facilitated the indication of gaps in this law/policy in not providing a given requirement in the appropriate form suggested by the SSF Guidelines. The results of this preliminary assessment are provided in [Table 1].

Notwithstanding the adoption of the NFALP five years before the SSF Guidelines were endorsed, certain elements of this international instrument were already enshrined in that Brazilian law and policy. The selected provisions of the NFALP law do find corresponding provisions in the SSF Guidelines, but when analyzed in scrutiny, the NFALP fails to address more specific matters that are pivotal for SSF. This [Table 1], therefore, is a useful tool that may help the legal practitioner to visualise the extent to which these issues addressed by the NFALP conform with the SSF Guidelines. The identified gaps of the NFALP show that it is not possible to rely solely on that law when implementing the guidelines in Brazil. These gaps illuminate those specific matters, which need further attention and which can be better addressed by interpretation and application of the NFALP in combination with other legal and policy instruments from different domains, notably in the environmental and human rights legal regimes. Such integrated way of applying the NFALP may well serve as an 'entry point' through which to better implement the SSF Guidelines in the country.

Table 1 here

There are, in fact, many other federal legal instruments that relate to fisheries as recently identified by a study, which indicated 175 legal documents at federal level and of various normative natures directly or indirectly influencing coastal fisheries management [48]. Other federal legislations are thus inherently important for SSF, but the objective of the present research was to put the NFALP in scrutiny as a fundamental step to examine the provisions that are relevant for the implementation of the SSF Guidelines and which issues can be better addressed by reading the NFALP in combination with other national instruments. In addition to the preliminary assessment, a more detailed and critical analysis was conducted using a simple methodology, aiming at addressing four main questions: (i) how the meaning of SSF is captured by the NFALP legislation? (ii) are the HRBA and the EAF provided by the NFALP legislation? (iii) what other provisions of the NFALP are relevant for SSF? and 
This is a peer-reviewed, accepted author manuscript of the following research article: Nakamura, J., \& Hazin, F. (2020). Assessing the Brazilian federal fisheries law and policy in light of the Voluntary Guidelines for Securing Sustainable Small-scale Fisheries. Marine Policy, 113 ,

[103798]. https://doi.org/10.1016/j.marpol.2019.103798

(iv) which other federal legal instruments are relevant to support the implementation of the SSF Guidelines?

In answering these four questions, the analysis took into account the express references to SSF sector in the examined legislation based on the different terminologies used (e.g. artisanal, subsistence, local, indigenous), the activities (e.g. preparation, harvesting, processing and marketing), people engaged (e.g. fisher with the groups of men, women, children, indigenous people) and tools used in these activities (e.g. vessel, fishing gear). The answers provide additional insights to the preliminary assessment in better understanding the extent to which the federal principal fisheries legislation/policy in Brazil supports the implementation of the SSF Guidelines. As the overall conclusion points to the need of an integrated interpretation and application of the NFALP and other federal legislations/policies, this analysis further outlines, in [Table 2], some of these specific federal legislations that complement the NFALP. Due to the multiple issues covered by the SSF Guidelines, [Table 2] presents a non-exhaustive list of relevant legislation. A more comprehensive assessment is beyond the scope of this article.

\subsection{Assessing the federal fisheries primary legislation in light of the SSF Guidelines}

\subsubsection{How the meaning of SSF is captured by NFALP legislation?}

The legal definition of SSF varies by country and the SSF Guidelines have not prescribed a standard nor any specific requirement for countries to meet in establishing their own legal understanding of what SSF is [20] (Subsection 2.4). The NFALP generally defines 'fishing activity' as comprising all processes of fishing, exploitation, exploration, harvesting, conservation, processing, transport, trade and research of fishery resources [47] (Article 4, caput). It does not use the term 'smallscale fisheries', which falls under any of such fishing activities. The specific provisions of the NFALP, which address the SSF sector, in turn, refer to SSF by three different meanings. One is 'artisanal fishing activity', which includes the confection and repair of fishing gears and small boats, as well as the processing of fish products from artisanal fishing [47] (Article 4, single paragraph). Another is 'commercial artisanal fishing', classified as the fishing practiced directly by professional fishers, autonomously or under a regime of family economy, with their own means of production or by partnership agreement, disembarked or using small boats [47] (Article $8, I(a))$. The third reference is of 'non-commercial subsistence fishing', which is categorized by the fishing practiced for non-profit purposes for domestic consumption or barter, using gears provided by specific legislation [47] (Article 8, II(c)). The NFALP also defines 'small-scale boats' used in commercial fishing as those with a capacity of less or equal to 20 gross tonnage [47] (Article 10, §1, I). 
This is a peer-reviewed, accepted author manuscript of the following research article: Nakamura, J., \& Hazin, F. (2020). Assessing the Brazilian federal fisheries law and policy in light of the Voluntary Guidelines for Securing Sustainable Small-scale Fisheries. Marine Policy, 113 ,

[103798]. https://doi.org/10.1016/j.marpol.2019.103798

The family economy regime referred in the NFALP is defined by the Federal Law No. 8,212/1991 on social security, meaning the activity in which the work of the members of the family is indispensable to their own subsistence and to the socioeconomic development of the family as a whole, being exercised in conditions of mutual dependency and collaboration without the use of permanent employees [49] (Article 12, §1). All those terminologies used in the NFALP are important in enforcing the NFALP's applicability to the entire SSF value chain, in accordance with the SSF Guidelines, addressing preparatory (preharvest), harvesting and processing (postharvest) activities, and taking into account the diverse contexts in which the SSF sector is inserted, both in formal and/or informal markets, conducted for commercial or subsistence purposes [20] (Subsections 2.1, 6.5, 6.6 and 7.1).

To a certain extent, the NFALP regulatory scope goes beyond the SSF Guidelines, which is focused on capture fisheries [20] (Subsection 2.2). In addition to capture fisheries, an entire section of the NFALP also applies and is devoted to aquaculture, including family aquaculture [47] (Article 19, IV), which may be conducted by SSF and which small-scale fishers' livelihoods can benefit from. The NFALP further ensures the people involved in capture fisheries and farming are beneficiaries of the national agriculture policy [47] (Article 27). The NFALP defines 'family aquaculture' as the aquaculture practiced by a family unit in accordance with the Federal Law No. 11,326/2006, which ensures that the National Policy for Family Agriculture and Rural Family Projects applies to fishers practicing artisanal fisheries, indigenous peoples, members of communities remainders of rural 'quilombos' and other traditional peoples and communities, provided that other conditions are met [50] (Article 3, §2, IV, V, VI). Being beneficiaries of such policy allow them to apply for financial credit lines, thus, in a way, the NFALP links opportunities for small-scale fishers to obtain economic support to conduct their aquaculture activities based on that other legislation.

\subsubsection{Are the HRBA and the EAF provided by NFALP legislation?}

The HRBA is the underlining principle that drives the implementation of the SSF Guidelines towards achieving their objectives [20] (Subsection 1.2). International human rights standards and principles, including respect of cultures, nondiscrimination, gender equality and equity, consultation and participation, are expressly provided in the SSF Guidelines [20] (Subsection 3.1(1) to (8)). In the context of SSF, a HRBA entails inclusive and equitable processes for the realization of both human rights entitlements and duties of small-scale fishers [21]. The adoption of such approach by any fisheries legislation and policy is fundamental to appropriately address the special needs of the vulnerable and marginalized SSF and at best avoid deepening the inequalities and unfair treatments to an within this sector. 
This is a peer-reviewed, accepted author manuscript of the following research article: Nakamura, J., \& Hazin, F. (2020). Assessing the Brazilian federal fisheries law and policy in light of the Voluntary Guidelines for Securing Sustainable Small-scale Fisheries. Marine Policy, 113 ,

[103798]. https://doi.org/10.1016/j.marpol.2019.103798

The SSF duties, in turn, include their responsibilities to conserve and protect the marine environment and not contribute to overexploitation, in accordance with an EAF. The SSF Guidelines follow an EAF [20] (Subsections 3.1(11) and 6.1), which essentially demands for a balanced, integrated and holistic management of fishery resources, taking into account all associated species, habitats, biodiversity and ecosystem interactions [14]. The guidelines also recognize the role of SSF in the restoration, conservation, protection and co-management of aquatic ecosystems, as well as the importance of SSF in utilizing non-harmful fishing practices to the aquatic environment and associated ecosystems [20] (Subsections 5.5 and 5.14). The human element as part of this broad environment also means the recognition of all fishers' participation in managing and conserving fisheries and the marine environment as a whole [17].

With a hybrid normative and policy nature, the NFALP contains provisions that use vague or generic language that does not create substantive rights to the SSF sector, persons, legal or natural, nor particular duties to the State. However, the NFALP does resonate broadly with social and environmental objectives that the SSF Guidelines call for, enshrining both a HRBA and EAF, at least to a certain extent. The alignment with such approaches is more evident from the outset where the objectives of the NFALP include the sustainable development of fisheries and aquaculture as sources of food, job, income, leisure, ensuring the sustainable use of fishery resources as well as the optimization of their economic benefits, in balance with the preservation and conservation of the environment and biodiversity; the preservation, conservation and restoration of fishery resources and aquatic ecosystems, the socio-economic, cultural and professional development of people practicing fishing activities as well as their communities [47] (Article 1, I, III, IV).

Considerations of the HRBA and EAF are also enshrined in the NFALP where it provides for the competence of public authorities to regulate the NFALP, conciliating the balance between the principle of sustainability of fishery resources and the achievement of best economic and social results, also taking into account peculiarities and needs of artisanal and subsistence fishers with a view to ensure their permanence and continuity [47] (Article 3, caput, §1). Other relevant provisions of the NFALP for HRBA and EAF contemplate: a) social participation, capacity-building of the fisheries workforce and financial credit for the promotion of the fisheries sector, as tools through which sustainable development of fisheries should be realized [47] (Article 7, III, IV, $\mathrm{X}$; b) the protection of ecosystems and the maintenance of ecological balance, in accordance with the principles of biodiversity preservation and sustainable use of natural resources; and c) the search for mechanisms that guarantee the protection and security of fishworkers and populations with traditional knowledge [47] (Article 5, I, II). 
This is a peer-reviewed, accepted author manuscript of the following research article: Nakamura, J., \& Hazin, F. (2020). Assessing the Brazilian federal fisheries law and policy in light of the Voluntary Guidelines for Securing Sustainable Small-scale Fisheries. Marine Policy, 113 ,

[103798]. https://doi.org/10.1016/j.marpol.2019.103798

Though in a soft manner, the NFALP provides that fishing activities may be temporarily, periodically or permanently prohibited for the protection of threatened species, areas or ecosystems, as well as for the protection of the worker [47] (Article $6, I, I V)$, which again aligns respectively with both EAF and HRBA. An EAF is also subtly reflected in the monitoring, control and surveillance (MCS) provision, which expressly includes the environmental monitoring of aquatic ecosystems [47] (Article 31, caput). The NFALP, however, has only a couple of provisions addressing MCS, failing to elaborate on the EAF's human dimension and stakeholders' involvement, including of small-scale fishers in MCS [17, 19], as well as the need to support MCS systems that are suitable to SSF [20] (Subsection 5.16). The fisheries offences and penalties, in turn, are not regulated by the NFALP, which refers to the Federal Law No. 9,605/1998 on environmental crimes and administrative sanctions and its regulation [51] for the appropriate applicability [47] (Article 33).

In relation to other vulnerable groups within SSF, the NFALP is limited to solely address specific provisions for children that are engaged in fishing activities, as called for in the SSF Guidelines [20] (Subsection 6.12, 6.17). Children labor in fisheries is permitted therein as long as they are over fourteen years old and work under the condition of apprentice in accordance with the legislation on labor, social security, protection of the child and adolescent and norms of the maritime authority [47] (Article $10, \S 5)$. In this respect, it is important to note that on the year that Brazil ratified the Convention on the Rights of the Child [52], the country enacted a federal law for the protection of the child and adolescent, as outlined further below.

Special treatment to women and indigenous peoples engaged in SSF was, to an extent, also addressed with the enactment of the NFALP's regulation, the Federal Decree No. 8,425/2015, which exempted certain fishers - expressly fishermen and fisherwomen of subsistence, amateurs, and indigenous peoples practicing subsistence fisheries - from the obligation to register in the General Registry of Fishing Activity (GRFA) as a pre-condition to obtain the applicable administrative act enabling them to exercise fishing activities [53] (Article 3, §1). This decree illustrates how the law can provide for the special attention to women and indigenous peoples, as required by the SSF Guidelines [20] (Subsections 3.1(2)(4), 5.4, Section 8).

In addition to the GRFA, the NFALP [47] (Article 24) and its regulation [53] (Article 14, I) require all persons, natural or legal, engaged in fishing to be registered in the Federal Technical Registry within the national environmental agency- IBAMA. This registration is part of the environmental instruments provided by the Federal Law No. 6,938/1981 on the National Environmental Policy [54], adding another element of an EAF to the NFALP. With respect to sustainable development of the fishing activity in general, the NFALP provides that it shall be implemented by taking into account inter alia social participation, training of the fisheries workforce, development of an 
This is a peer-reviewed, accepted author manuscript of the following research article: Nakamura, J., \& Hazin, F. (2020). Assessing the Brazilian federal fisheries law and policy in light of the Voluntary Guidelines for Securing Sustainable Small-scale Fisheries. Marine Policy, 113 ,

[103798]. https://doi.org/10.1016/j.marpol.2019.103798

information system on the fisheries activity, credit for the promotion of the fisheries sector and research for the permanent provision of related information and scientific data [47] (Article 7, III, IV, VIII, X). It also requires the capacity building of the workforce to be guided for the sustainable development of the fisheries activity and enforces the responsibility of public authorities and private initiatives to promote research, with the respective results outreached to all [47] (Articles 29 and 30).

\subsubsection{What other provisions of the NFALP legislation are relevant for SSF?}

There are certain provisions of the NFALP that are not directly linked to neither a HRBA nor an EAF, but which are still important in relation to SSF and concern other more specific SSF Guidelines' requirements. For instance, the NFALP highlights the need to observe the norms of the maritime authority applicable to the type of vessels when such vessels that are used in artisanal fishing do not engage in fishing but instead are used for transporting families of fishers, products of small crops and domestic industry [47] (Article 10, §4). This provision seems to be more of maritime security and sea safety concerns, which are important to consider in addressing the risks to which small-scale fishers are exposed in doing such transportation, as highlighted by the SSF Guidelines [20] (Subsection 6.17).

Other two examples concern SSF's labour rights. The first one is on the possibility of using the vessels, nets and other tools and equipment used in artisanal fisheries as laboring tools for the purpose of financial credit [47] (Article 10, §3), which partially meets the requirement on access to services, like credit schemes, as provided by the SSF Guidelines [20] (Subsection 6.4). The second addresses the fishing associations (Colônia de Pesca), allowing them to organize the trade of fishery products of their associates, directly or through cooperatives or other entities established particularly for such purposes [47] (Article 28), as also suggested by the SSF Guidelines [20] (Subsection 7.4).

\subsubsection{Which other federal legal instruments are relevant to support the implementation of the SSF Guidelines?}

The Brazilian Federal Constitution contains a number of provisions that reflect a HRBA [35] (e.g. Article 3, I to IV, Article 5, I, IV, XIV, XXII and Article 6) and also provides for the free professional or syndical association of fishing associations [35] (Article 8 , Single Paragraph). This particular provision is regulated by the Federal Law No. 11,699/2008, which recognizes inter alia the fishing associations, the states' federations and the national confederation of fishers as labor unions of the artisanal fisheries sector, which represent artisanal fishers and are responsible to defend their interests and rights in courts or outside courts within their respective jurisdiction [55] (Articles 1, 2, 4). An important institutional arrangement for the representation of the 
This is a peer-reviewed, accepted author manuscript of the following research article: Nakamura, J., \& Hazin, F. (2020). Assessing the Brazilian federal fisheries law and policy in light of the Voluntary Guidelines for Securing Sustainable Small-scale Fisheries. Marine Policy, 113 ,

[103798]. https://doi.org/10.1016/j.marpol.2019.103798

small-scale fishers used to be the recently extinguished National Council of the Traditional Peoples and Communities, which had been established by the Federal Decree No. 8,750/2016 [56]. This decree required that at least one representative of certain interest groups, including indigenous peoples and artisanal fishers, participates in it [56] (Article 4, §2, I, V). The current government, however, enacted a recent Federal Decree No. 9,759/2019 [57], which extinguished all the federal public administration's joint committees established by decree [57] (Article 1, §1, I), the consequence of which was the extinction of the mentioned National Council of the Traditional Peoples and Communities. The Labour Party has filed an action with a request of provisional measures challenging the constitutional authority of that 2019's decree, but the decision of the Federal Supreme Court found that it is in accordance with the Brazilian Constitution the extinction, by the president's federal decree of joint committees which had been created by the same form of legal instrument [58]. The extinction of that National Council therefore remains. An alternative solution appears to be the re-creation of the council pursuant to the applicable procedures [57] (Article $6)$.

It would have been possible to assert, based on those representative bodies and the foreseen provision of the NFALP [47] (Article 28), that there was in Brazil a supportive legal framework for the SSF to be appropriately represented, but this latest normative shift has imposed an evident shadow on the representation of SSF upon the federal government. The labour unions of the artisanal sector nevertheless may offer an important feature for securing this sector's participation, which partially address their representation in legal and policy decision-making as well as in ensuring collaboration with other stakeholders and policy coherence [20] (Subsections 3.1(6), $7.4,10.6$ to 10.8$)$.

The National Strategic Plan for Protected Areas established by the Federal Decree No. 5,758/2006 [59] is also an important initiative of the federal government in implementing the human rights principles of consultation, participation, rule of law and transparency [20] (Subsection 3.1(6)(7)(8)) in the creation and co-management of coastal and marine protected areas, aiming to align the conservation of biological diversity with the recovery of fishery resources. It promotes social participation in all stages of implementation and evaluation of the plan and ensures the involvement and qualification of the different social actors in the decision-making process, guaranteeing the respect to the knowledge and the rights of indigenous peoples, quilombolas and local communities. It also ensures that the outreach of information about the plan is provided in accessible language [59] (Annex, Sections 1.2 and 4.2). This strongly aligns with the EAF and the related provisions of the SSF Guidelines [20] (Subsections $3.1(11), 5.13$ to 5.15 and 6.1). 
This is a peer-reviewed, accepted author manuscript of the following research article: Nakamura, J., \& Hazin, F. (2020). Assessing the Brazilian federal fisheries law and policy in light of the Voluntary Guidelines for Securing Sustainable Small-scale Fisheries. Marine Policy, 113 ,

[103798]. https://doi.org/10.1016/j.marpol.2019.103798

With regards to tenure rights of the SSF sector that occupies public lands, as addressed by the SSF Guidelines [20] (Subsections 5.1 to 5.10), the Federal Law No. $9,985 / 2000$, which established the National System of Nature Conservation Units provides for two protected areas of particular interest to SSF: the marine extractive reserves (MERs) and the reserves for sustainable development (RSDs) [58] (Articles $18, \S 1,20)$. These are areas of public domain created for the purpose of aligning the activities and living conditions of traditional peoples, in which SSF communities are included, with the sustainable use of natural resources. The regulatory Federal Decree N. 4,430/2002 includes, within the process for creation of those areas, provision for prior public consultation with the local population and any other interested actor, and the possibility for the institution of a consultative or deliberative council composed by representatives of the traditional population and local residents [59] (Articles 4, 5, 17, §2). Proceedings on resettlement of and compensation for traditional populations ensure that the location and conditions are agreed between the public authority and the affected parties [60] (Article 42) [60] (Articles 35 to 39).

Additionally, in respect of access to justice [20] (Subsection 5.11), Brazil has a supporting legal framework, which nevertheless is hindered by the lengthy processes and other difficulties in practice. For small-scale fishers, who predominately have lowincome and poor level of education, legal assistance is provided by the Public Defender's Office (PDO), a permanent institution dedicated to legal aid, promotion of human rights and the free-of-charge defense of individual and collective rights to needy people, in all jurisdiction levels inside as well as outside the courts [35] (Articles 92, 134). Each state of Brazil and the Federal District have their own PDO, but this service is not reachable by many SSF communities and vulnerable peoples living in remote locations under conditions of resignation, with poor or even absence of basic infrastructure, transportation and other services. Some states have implemented projects of the so-called itinerant justice, which involve teams of civil servants from various public institutions that travel for approximately ten days to remote locations, aiming to 'take justice' and other public services to remote communities [62]. This is an important initiative taken by certain states to facilitate access to justice for SSF communities, which are assisted with essential legal proceedings such as obtaining registry or rectification of birth certificates, stable unions, divorce, etc. [62, 63].

Small-scale fishers, under the representation of their respective local fishing associations, state federations or national confederation, may also collectively claim their rights and interests by bringing an action to court. For instance, the National Confederation of Fishers and Aquaculturists, representing the interests of artisanal fishers, has filed one constitutional action ADPF No. 389/MC to the Federal Supreme Court with a request of provisional measures in order to receive benefits deriving from certain periods in which closed seasons were temporarily suspended by an inter- 
This is a peer-reviewed, accepted author manuscript of the following research article: Nakamura, J., \& Hazin, F. (2020). Assessing the Brazilian federal fisheries law and policy in light of the Voluntary Guidelines for Securing Sustainable Small-scale Fisheries. Marine Policy, 113 ,

[103798]. https://doi.org/10.1016/j.marpol.2019.103798

ministerial act, arguing that such benefits were not appropriately granted to the fishers. The court rejected such request, but a final decision on the case has not been rendered yet [64].

Social security issues called for in the SSF Guidelines [20] (Subsection 6.3) are addressed by other federal legal instruments. Constitutional provisions ensure that the artisanal fishers and their respective spouses participate in and benefit from social security system by contributing with an aliquot over the production sold [35] (Article $195, \S 8)$. Pursuant to these and other applicable requirements, the artisanal fisherman and the artisanal fisherwoman are both entitled the right to a retirement pension. Such other requirements include working under a family economy regime and provided that the artisanal fisherman is 60 years old and the artisanal fisherwoman is 55 , which accounts for at least five years less than the average ages for retirement pension for other categories of men and women workers [35] (Article 201, §7, II). The other benefits covered by the national social security system e.g. assistance in the event of temporary or permanent incapacity to work, as well as maternity protection, are guaranteed to artisanal fishers who undertake similar fishing activities as their habitual occupation or as their means of livelihood, provided that they apply for the appropriate qualification in the National Social Security Institute (NSSI) to receive such benefits [49](Article 12, VII(b)) and [65](Article $11 \mathrm{VII}(\mathrm{b})$ ).

In addition to the labour issues addressed by the NFALP, other related guarantees support the requirements of the SSF Guidelines [20] (Subsections 6.4 to 6.8). Artisanal fishermen and fisherwomen acting autonomously or under a family economy regime, have the right to unemployment assistance during the closed season, when fisheries is temporarily prohibited for the conservation of the stocks or due to natural disasters or accidents, provided they meet certain requirements e.g. undertake the artisanal fisheries activity exclusively and continuously, are registered in the GRFA and are qualified as 'special assured persons' in the NSSI [66]. This assistance corresponds to the amount of one monthly minimum wage throughout the closed season, which is determined now by the MALFS. Recently, the federal government imposed more restrictions to this rule, prohibiting subsistence fishers and indigenous peoples from receiving this particular benefit and prohibiting artisanal fishers from receiving it in cases where there is availability of alternative fisheries activities within the fishing area where the closed season is established [67].

In relation to climate change issues outlined by the SSF Guidelines [20] (Section 9 ), the Brazilian legal and policy framework seems to have addressed a limited connection with the SSF issues. The National Policy on Climate Change established by the Federal Law 12,187/2009 does not make any particular reference to SSF, but does include in its objectives the implementation of adaptation measures at federal, state and municipal levels, taking into account the participation and cooperation of the 
This is a peer-reviewed, accepted author manuscript of the following research article: Nakamura, J., \& Hazin, F. (2020). Assessing the Brazilian federal fisheries law and policy in light of the Voluntary Guidelines for Securing Sustainable Small-scale Fisheries. Marine Policy, 113 ,

[103798]. https://doi.org/10.1016/j.marpol.2019.103798

economic and social beneficiaries, including those especially vulnerable to the adverse effects of climate change [68] (Article 4, V). SSF activities and communities could also benefit from the National Climate Change Fund, one of the instruments provided by that policy [68] (Article 6, II). As such, sustainable SSF activities as well as related research and projects could obtain financial support from such fund based on the fact that this fund aims to provide resources for the support of projects or studies designed for climate change mitigation and adaptation, including the support to sustainable productive chains, which encompasses SSF [68].

\subsection{Identifying other federal legislations relevant for SSF}

The previous subsection informed how the NFALP addresses certain questions and how other federal legislations and instruments that are relevant for SSF should be read, interpreted and applied in combination with the NFALP with respect to particular issues called upon by the SSF Guidelines. The last question answered above, in particular, shed light to those remaining matters that the SSF Guidelines provide for but that are not addressed by the NFALP, rather being supported by other federal legal instruments as well as the Brazilian Federal Constitution. The country has a number of other federal legislation that establishes policies relevant for the special consideration given to people involved in the SSF sector, such as the Federal Decree No. 6,040/2007, providing for the National Policy on the Sustainable Development of Traditional Peoples and Communities [69], the Federal Decree No. 5,300/2004 [71] regulating the Federal Law No. 7,661/1988, which establishes the National Plan for Coastal Management [70], the Federal Decree No. 9,586/2018, establishing the National System of Policies for Women and the National Plan to Combat Domestic Violence [72] and the Federal Law No. 8,069/1990 providing for the Statute of the Child and Adolescent [73]. The list of selected Brazilian federal legal instruments relevant to SSF is summarized in [Table 2].

\section{Table 2 here}

When implementing the SSF Guidelines in Brazil, it is important, therefore, to combine the NFALP with all these other relevant federal legislations. The applicability of one particular legal instrument or more to address a given issue will, nevertheless, depend on the circumstances faced on the ground. The outline proposed in this article aims to assist the legal practitioners and decision-makers when dealing with the variety of matters that the SSF Guidelines cover and ensure all of them are appropriately supported by federal legislation and policies, which are fundamental in setting the minimum standards for the sub-national institutions, legal and policy instruments to comply with. An integrated analysis that link these federal instruments thus provides a more comprehensive and enforceable national legal and policy framework for the SSF sectors' recognition, empowerment and protection in Brazil and 
This is a peer-reviewed, accepted author manuscript of the following research article: Nakamura, J., \& Hazin, F. (2020). Assessing the Brazilian federal fisheries law and policy in light of the Voluntary Guidelines for Securing Sustainable Small-scale Fisheries. Marine Policy, 113 ,

[103798]. https://doi.org/10.1016/j.marpol.2019.103798

can also facilitate the application of the SSF Guidelines in other countries with similar legal and political structures.

\section{Conclusions}

The SSF Guidelines is an instrument founded on a HRBA, follows an EAF and provides for numerous issues in a holistic and innovative manner. It is part of recent developments of International Fisheries Law, bridging important elements of human rights and environmental protection to sustainable use, management and development of fisheries, focusing on one particular sector, the SSF. This article emphasized the importance of the SSF Guidelines from the global context to a particular country, Brazil, informing legal practitioners and decision-makers the extent to which the main federal principal fisheries legislation/ policy, the NFALP, is aligned with that international instrument. Unsurprisingly, this instrument, which was adopted few years before the endorsement of the SSF Guidelines, contains many gaps and does not sufficiently address various requirements of the SSF Guidelines. Though some important provisions do recognize the SSF, including them in the general scope of that law/policy, there are numerous matters which remain unaddressed by the NFALP, particularly on participation, gender equality and climate change.

Developing a new law to replace the NFALP or proposing amendments to it seems unrealistic given the many constraints facing the Brazilian federal institutional framework and the instability of the public structures governing fisheries and aquaculture. The issues not appropriately covered or not addressed at all by the NFALP may, however, be supported by other federal legislation and policies, as highlighted above. More detailed analysis of each of these other instruments and the extent to which they fulfill the gaps of the NFALP make room for future investigations. Such comprehensive evaluation that goes beyond the analysis of fisheries legislation requires political will to ultimately ensure that the currently in-force laws and policies are applied in coordination, aligning with the SSF Guidelines' requirements on policy coherence, institutional coordination and collaboration [20] (Section 10). It is fundamental that all relevant authorities, public and private institutions and other stakeholders that are involved in SSF issues appropriately communicate with each other, collaborate and act accordingly in coordinated efforts.

The purpose of this article was to ultimately shed light on the importance of a holistic and integrated view when examining a country's legal and policy framework in ensuring that it is aligned with the SSF Guidelines. It is likely that, as in Brazil, various legislations and policies (and not necessarily the main fisheries legislation and policy) are relevant and should be interpreted and applied in an integrated and complementary manner for the benefit of the SSF sector. This broad outlook at federal level is crucial in setting the fundamental standards based on which all subnational 
This is a peer-reviewed, accepted author manuscript of the following research article: Nakamura, J., \& Hazin, F. (2020). Assessing the Brazilian federal fisheries law and policy in light of the Voluntary Guidelines for Securing Sustainable Small-scale Fisheries. Marine Policy, 113 ,

[103798]. https://doi.org/10.1016/j.marpol.2019.103798

institutions, legislation and policies should be prepared, maintained, implemented and reviewed, to guarantee an adequate and effective implementation of the SSF Guidelines.

\section{References}

1. S.W. Purcell, R.S. Pomeroy, Driving Small-scale Fisheries in Developing $\begin{array}{llllll}\text { Countries, } & \text { Front. } & \text { Mar. } & \text { Sci. } & 2 & \text { (2015) }\end{array}$ https://doi.org/10.3389/fmars.2015.00044.

2. R. Chuenpagdee, S. Jentoft, Situating Poverty: A Chain Analysis of Small-Scale Fisheries, in: S. Jentoft, A. Eide (Eds.), Poverty Mosaics: Realities and Prospects in Small-scale Fisheries, Springer Netherlands, Dordrecht, 2011, pp. 27-42. https://doi.org/10.1007/978-94-007-1582-0_3.

3. C. Béné, C. Hersoug, E.H. Allison, Not by Rent Alone: Analyzing the Pro-Poor Functions of Small-Scale Fisheries in Developing Countries, Dev. Policy Rev. 28 (2010) 325-358, https://doi.org/10.1111/j.1467-7679.2010.00486.x.

4. J. Jacquet, D. Pauly, Funding Priorities: Big Barriers to Small-Scale Fisheries, Conserv. Biol. 22 (2008) 832-835. http://doi.org/10.1111/j.15231739.2008.00978.x.

5. H. Smith, X. Basurto, Defining Small-Scale Fisheries and Examining the Role of Science in Shaping Perception of Who and What Counts: A Systematic Review, Front. Mar. Sci. 6 (2019) 1-19. https://doi.org/10.2289/fmars.2019.00236.

6. S. Jentoft, R. Chuenpagdee, M.J. Barragán-Paladines, N. Franz (Eds.) The SmallScale Fisheries Guidelines: Global Implementation. Springer Switzerland, Cham, 2018.

7. D. Diz, E. Morgera, Insights for Sustainable Small-scale Fisheries, in: K. Schreckenberg, G. Mace, M. Poudyal (Eds.), Ecosystem Services and Poverty Alleviation: Trade-Offs and Governance, Routledge, New York, 2018, pp. 288301.

8. E. Morgera, M. Ntona, Linking Small-Scale Fisheries to International Obligations on Marine Technology Transfer, Marine Policy 93 (2018) 295-306. https://doi.org/10.1016/j.marpol.2017.07.021.

9. D. Rocklin, Who's Who in Small-Scale Fisheries, in: R. Chuenpagdee, D. Rocklin (Eds.), Small-scale fisheries of the world, TBTI Publication Series, St John's, Vol. I, 2016.

10. J.G.C. Oliveira Jr., L.P.S. Silva, A.C.M. Malhado, V.S. Batista, N.N. Fabré, R.J. Ladle, Artisanal Fisheries Research: A Need for Globalization?, PLOS One 11 (2016) 1-10. https://doi.org/10.1371/journal.pone.0150689.

11. Agreement for the Implementation of the Provisions of the United Nations Convention on the Law of the Sea relating to the Conservation and Management 
This is a peer-reviewed, accepted author manuscript of the following research article: Nakamura, J., \& Hazin, F. (2020). Assessing the Brazilian federal fisheries law and policy in light of the Voluntary Guidelines for Securing Sustainable Small-scale Fisheries. Marine Policy, 113 ,

[103798]. https://doi.org/10.1016/j.marpol.2019.103798

of Straddling Fish Stocks and Highly Migratory Fish Stocks, opened for signature on 4 August 1995 in New York, entered into force on 11 December 2001, 2167 UNTS 3.

12. FAO Code of Conduct for Responsible Fisheries, Rome, adopted on 31 October 1995 in Rome, Resolution 4/95, FAO Conferece.

13. Kyoto Declaration, adopted at the International Conference on the Sustainable Contribution of Fisheries to Food Security, in Kyoto, 4 to 9 December 1995.

14. FAO Fisheries Department. The Ecosystem Approach to Fisheries. FAO Technical Guidelines for Responsible Fisheries. No. 4, Suppl. 2. Rome, FAO. 2003. 112 p.

15. FAO Voluntary Guidelines on the Progressive Realization of the Right to Adequate Food in the Context of National Food Security, adopted at the 127th Session of the FAO Council, in Rome, November 2004.

16. FAO Fisheries Department. Increasing the Contribution of Small-Scale Fisheries to Poverty Alleviation and Food Security. FAO Technical Guidelines for Responsible Fisheries. No. 10. Rome, FAO. 2005. 79 p.

17. C. De Young, A. Charles, A. Hjort, Human Dimensions of the Ecosystem Approach to Fisheries: an Overview of Context, Concepts, Tools and Methods. FAO Fisheries Technical Paper. No. 489. Rome, FAO. 2008. 152 p.

18. FAO Voluntary Guidelines on the Responsible Governance of Tenure of land, fisheries and forests in the Context of National Food Security, adopted at the 38th (Special) Session of the Committee on World Food Security, in Rome, on 11 May 2012.

19. P. Cacaud, S. Cosentino-Roush, A How-to Guide on legislating for an ecosystem approach to fisheries. EAF-Nansen Project Report. No. 27. Rome, FAO. 2016. 56 p.

20. FAO Voluntary Guidelines for Securing Sustainable Small-Scale Fisheries in the Context of Food Security and Poverty Eradication, adopted at the 31st Session of the Committee on Fisheries, in Rome, June 2014.

21. S. Yeshanew, N. Franz, L. Westlund, Exploring the human rights-based approach in the context of the implementation and monitoring of the SSF Guidelines. FAO Fisheries and Aquaculture Proceedings. No. 53. Rome, FAO. 2016. 96 p.

22. United Nations General Assembly. Transforming our world: the 2030 Agenda for Sustainable Development. Resolution 701 of 25 September 2015. UN Doc. A/RES/70/1, 21 October 2015.

23. A. Said, R. Chuenpagdee. Aligning the Sustainable Development Goals to the Small-Scale Fisheries Guidelines: A case for EU Fisheries Governance, Marine Policy 107 (2019) 1-7. https://doi.org/10.1016/j.marpol.2019.103599. 
This is a peer-reviewed, accepted author manuscript of the following research article: Nakamura, J., \& Hazin, F. (2020). Assessing the Brazilian federal fisheries law and policy in light of the Voluntary Guidelines for Securing Sustainable Small-scale Fisheries. Marine Policy, 113 ,

[103798]. https://doi.org/10.1016/j.marpol.2019.103798

24. C.A. Courtney, R. Pomeroy, S.H. Brooks, Tacking Stocks of the Status of Implementation of the Voluntary Guidelines for Securing Sustainable Small-Scale Fisheries: A Country-Level Assessment Framework, Marine Policy 100 (2019) 361-370. https://doi.org/10.1016/j.marpol.2018.12.005.

25. E.J. Molenaar, R. Caddel, International Fisheries Law: Achievements, Limitations and Challenges, in: R. Caddel, E.J. Molenaar (Eds.), Strengthening International Fisheries Law in an Era of Changing Oceans, Bloomsbury Publishing PLC, Oxford, 2019, pp. 3-12.

26. M.A. Palma, M. Tsamenyi, W. Edeson, Promoting Sustainable Fisheries: the International Legal and Policy Framework to Combat Illegal, Unreported and Unregulated Fishing, Nijhoff, Leiden, 2010. https://doi.org/10.1163/ej.9789004175754.i-341.

27. Brasil. Secretaria de Planejamento e Investimento Estratégico do Ministério do Planejamento, Orçamento e Gestão. Plano Plurianual 2016-2019 _ desenvolvimento, produtividade e inclusão social - Mensagem Presidencial [Pluriannual Plan 2016-2019 - development, productivity and social inclusion]. Policy Plan. Brasília, Ministério do Planejamento, Orçamento e Gestão. 2015.

28. V. Carlson (Coord.), A. Vanin (Ed.), $1^{\circ}$ Anuário Brasilerio da Pesca e Aquicultura 2014 [1st Brazilian Fishery and Aquaculture Yearbook 2014]. Associação Cultural e Educacional Brasil (ACEB). 2014.

29. Brasil. Secretaria de Monitoramento e Controle do Ministério da Pesca e Aquicultura. Boletim Estatístico da Pesca e Aquicultura 2011 [Statistical Bulletin of Fisheries and Aquaculture 2011]. Policy Bulletin. Brasília, Ministério da Pesca e Aquicultura. 2011.

30. A.C. Diegues, A Sócio-Antropologia das Comunidades de Pescadores Marítimos no Brasil [The Socio-Antropology of Maritime Fishers Communities in Brazil] Etnografica III (1999) 361-375.

31. A.G. Campos, J.V. Chaves, Perfil Laboral dos Pescadores Artesanais: Insumos para o Programa Seguro Defeso [Labour Profile of Artisanal Fishers: Subsidies for the Closed Season's Insurance Scheme], Mercado de Trabalho 60 (2016) 6373. http://repositorio.ipea.gov.br/handle/11058/6625.

32. N.T. Azevedo, N. Pierri, A politica pesqueira no Brasil (2003-2011): a Escolha pelo Crescimento Produtivo e o Lugar da Pesca Artesanal [Fisheries Policy in Brazil (2003-2011): the Choice for Production Growth and the Place of Artisanal Fisheries], Desenvolvimento e Meio Ambiente, 32 (2014) 61-80.

33. L.M. Hellebrandt, P.R. Abdallah, D. Hellebrandt, Avaliação de políticas públicas aplicadas à pesca artesanal no Brasil [Evaluation of the Public Policies Applied to the Artisanal Fisheries in Brazil], Encontro Nacional da ANPPAS (2012) 6. 
This is a peer-reviewed, accepted author manuscript of the following research article: Nakamura, J., \& Hazin, F. (2020). Assessing the Brazilian federal fisheries law and policy in light of the Voluntary Guidelines for Securing Sustainable Small-scale Fisheries. Marine Policy, 113 ,

[103798]. https://doi.org/10.1016/j.marpol.2019.103798

34. Brasil. Instituto Brasileiro de Geografia e Estatística - IBGE. Anuário Estatístico do Brasil [Brazil's Annual Statistics Report]. Report. Vol. 74. Brasília, IBGE, Ministério do Planejamento, Orçamento e Gestão. 2014.

35. Brasil. Constituição (1988) Constituição da República Federativa do Brasil: promulgada em 5 de outubro de 1988 [Constitution of the Brazilian Federal Republic: enacted on 5 October 1988]. Organização do texto: Juarez de Oliveira. 4 ed. São Paulo: Saraiva, 1990. 168 p. (Série Legislação Brasileira).

36. Brasil. Medida Provisória No. 870 de $1^{\circ}$ de Janeiro de 2019 [Provisional Measure No. 870 of 1 January 2019]. Diário Oficial da União, Brasília, DF, P. 1, Special Edition of 1 January 2019.

37. M.L. Ruffino, A Gestão dos Recursos Pesqueiros no Brasil [The Management of Fishery Resources in Brazil], in: A. Marcos (Ed.), Repensando a Gestão Ambiental no Brasil: uma Contribuição ao Debate de Reconstrução Nacional [Rethinking Environmental Management in Brazil: a Contribution to the Debate of National Reconstruction], Kindle, Belo Horizonte, 2016.

38. L.R. Gonçalves, The Role of Brazil in the International Commission for the Conservation of Atlantic Tunas (ICCAT), Rev. Bras. Polit. Int. 2 (2019) 1-19. http://dx.doi.org/10.1590/0034-7329201900201.

39. FAO. The State of the World Fisheries and Aquaculture 2018 - Meeting the Sustainable Development Goals. Rome, FAO. 2018. 210 p.

40. A.P. Da Silva, Pesca Artesanal Brasileira - Aspectos Conceituais, Históricos, Institucionais e Prospectivos [Brazilian Artesanal Fisheries - Conceptual, Historic, Institutional and Prospective Aspects]. Palmas: Embrapa Pesca e Aquicultura, 2014.

41. Brasil. Portal Legislativo. Constituições Estaduais [Brazilian States' Constitutions]. http://www4.planalto.gov.br/legislacao/portal-legis/legislacaoestadual/constituicoes-estaduais (accessed 13 November 2019).

42. C.S. Seixas, D.C. Kalikoski, T. Almudi, V.S. Batista, A.L. Costa, H.L. Diogo, B.P. Ferreira, C.R.T. Futemma, R.L. Moura, M.R. Ruffino, R. De Salles, A.P.G. Thé, Gestão Compartilhada do Uso de Recursos Pesqueiros no Brasil: Elementos para um Programa Nacional [Co-management of the Use of Fishery Resources in Brazil: Elements for a National Program], Ambient. Soc. 14 (2011) 23-44. https://doi.org/10.1590/S1414-753X2011000100003.

43. S. Jentoft, M. Bavinck, Interactive Governance for Sustainable Fisheries: Dealing with Legal Pluralism, Current Opinion in Environmental Sustainability 11 (2014) 71-77. https://doi.org/10.1016/j.cosust.2014.10.005.

44. S. Jentoft, Legal Pluralism and the Governability of Fisheries and Coastal Systems, The Journal of Legal Pluralism and Unofficial Law, 43 (2011) 149-172. https://doi.org/10.1080/07329113.2011.10756673. 
This is a peer-reviewed, accepted author manuscript of the following research article: Nakamura, J., \& Hazin, F. (2020). Assessing the Brazilian federal fisheries law and policy in light of the Voluntary Guidelines for Securing Sustainable Small-scale Fisheries. Marine Policy, 113 ,

[103798]. https://doi.org/10.1016/j.marpol.2019.103798

45. S.D.P. Trevizan, B.M. Leão, Legal Pluralism: its Importance for the Environmental Sustainability in Traditional Communities, Sociedade e Estado 29 (2014) 539-560. https://doi.org/10.1590/S0102-69922014000200011

46. O.M.B.A. De Oliveira, V.L. Da Silva, O processo de Industrialização do Setor Pesqueiro e a Desestruturação da Pesca Artesanal no Brasil a partir do Código da Pesca de 1967. [The Industrialization Process of the Fisheries Sector and the Disruption of the Artisanal Fisheries in Brazil from the 1967 Fisheries Code], Sequência $65 \quad$ (2012) 329-357. https://doi.org/10.5007/21777055.2012v33n65p329.

47. Brasil. Lei Federal No. 11,959 de 29 de junho de 2009 [Federal Law No. 11,959 of 29 June 2009]. Diário Oficial da União, Brasília, DF, P. 1 of 30 June 2009.

48. M.A.R.M. Vieira, C.R. dos Santos, C.S. Seixas, Oportunidades na Legislação Brasileira para Sistemas de Gestão Compartilhada da Costa Costeira [Opportunities for Fisheries Co-Management in Coastal Systems within Brazilian Legislation], Bol. Inst. Pesca 41 (2015) 995-1012.

49. Brasil. Lei Federal No. 8,212 de 24 de julho de 1991 [Federal Law No. 8,212 of 24 July 1991]. Diário Oficial da União, Brasília, DF, P. 14.801 of 25 July 1991.

50. Brasil. Lei Federal No. 11,326 de 24 de junho de 2006 [Federal Law No. 11,325 of 24 June 2006]. Diário Oficial da União, Brasília, DF, P. 1 of 25 July 2006.

51. Brasil. Lei Federal No. 9,605 de 12 de fevereiro de 1998 [Federal Law No. 9,605 of 12 February 1998]. Diário Oficial da União, Brasília, DF, P. 1 of 13 February 1998.

52. Convention on the Rights of the Child, opened for signature in 20 November 1989 in New York, entered into force on 2 September 1990.

53. Brasil. Decreto Federal No. 8,425 de 31 de março de 2015 [Federal Decree No. 8,425 of 31 March 2015]. Diário Oficial da União, Brasília, DF, P. 2 of 01 April 2015.

54. Brasil Lei Federal No. 6,938 de 31 de agosto de 1981 [Federal Law No. 6,938 of 31 August 1981]. Diário Oficial da União, Brasília, DF, P. 16509 of 02 September 1981.

55. Brasil. Lei Federal No. 11,699 de 13 de junho de 2008 [Federal Law No. 11,699 of 13 June 2008]. Diário Oficial da União, Brasília, DF, P. 8 of 16 June 2008.

56. Brasil. Decreto Federal No. 8,750 de 9 de maio de 2016 [Federal Decree No. 8,750 of 9 May 2016]. Diário Oficial da União, Brasília, DF, P. 1 of 10 May 2016.

57. Brasil. Decreto Federal No. 9,759 de 11 de Abril de 2019 [Federal Decree No. 9,759 of 11 April 2019]. Diário Oficial da União, Brasília, DF, P. 5 of 11 April 2019.

58. Brasil. Supremo Tribunal Federal. Ação Direta de Inconstitucionalidade - ADI No. 6121. Judicial Case (Electronic Public Process). Brasília, DF. 
This is a peer-reviewed, accepted author manuscript of the following research article: Nakamura, J., \& Hazin, F. (2020). Assessing the Brazilian federal fisheries law and policy in light of the Voluntary Guidelines for Securing Sustainable Small-scale Fisheries. Marine Policy, 113 ,

[103798]. https://doi.org/10.1016/j.marpol.2019.103798

http://portal.stf.jus.br/processos/detalhe.asp?incidente=5678906 $\quad$ (accessed 6 December 2019).

59. Brasil. Decreto Federal No. 5,758 de 13 de abril de 2006 [Federal Decree No. 5,578 of 13 April 2006]. Diário Oficial da União, Brasília, DF, P. 1 of 17 April 2006.

60. Brasil. Lei Federal No. 9,985 de 18 de julho de 2000 [Federal Law No. 9,985 of 18 July 2000]. Diário Oficial da União, Brasília, DF, P. 1 of 19 July 2000.

61. Brasil. Decreto Federal No. 4,340 de 22 de agosto de 2002 [Federal Decree No. 4,340 of 22 August 2002]. Diário Oficial da União, Brasília, DF, P. 9 of 23 August 2002

62. T. Freire, Meios de Acesso Variam para a Justiça Chegar aos Rincões mais Distantes do País [Measures for the Access to Justice Vary in order to Reach the Farthest Areas of the Country]. Press Release. Agência do Conselho Nacional de Justiça, published on 04 October 2013. https://www.cnj.jus.br/justica-usa-onibusou-barco-para-chegar-aos-rincoes-mais-distantes-do-pais/ (accessed 13 November 2019).

63. Brasil. Conselho Nacional de Justiça, Associação Nacional dos Magistrados Estaduais, Moradores de Vila de Pescadores recebe Serviços no Amapa. [Residents of Fishers Village receive Services in Amapa]. Press Release. CNJ, published on 07 January 2019. https://anamages.org.br/noticias/moradores-devila-de-pescadores-recebe-servicos-judiciais-no-amapa (accessed 13 November 2019).

64. Brasil. Supremo Tribunal Federal. Arguição de Descumprimento de Preceito Fundamental - ADPF No. 389. Judicial Case (Electronic Public Process). Brasília, DF. Rapporteur: Minister Roberto Barroso. http://portal.stf.jus.br/processos/detalhe.asp?incidente=4944271 (accessed 13 November 2019).

65. Brasil. Lei Federal No. 8,213 de 24 de junho de 1991 [Federal Law No. 8,213 of 24 June 1991]. Diário Oficial da União, Brasília, DF, P. 14809 of 25 July 1991.

66. Brasil. Decreto Federal No. 8,424 de 31 de março de 2015 [Federal Decree No. 8,424 of 31 March 2015]. Diário Oficial da União, Brasília, DF, P. 1 of 01 April 2015.

67. Brasil. Decreto Federal No. 9,578 de 22 de novembro de 2018 [Federal Decree No. 9,578 of 22 November 2018]. Diário Oficial da União, Brasília, DF, P. 47 of 23 November 2018.

68. Brasil. Lei Federal No. 12,187 de 29 de dezembro de 2009 [Federal Law No. 12, 187 of 29 December 2009]. Diário Oficial da União, Brasília, DF, P. 109 of 29 December 2009. 
This is a peer-reviewed, accepted author manuscript of the following research article: Nakamura, J., \& Hazin, F. (2020). Assessing the Brazilian federal fisheries law and policy in light of the Voluntary Guidelines for Securing Sustainable Small-scale Fisheries. Marine Policy, 113 , [103798]. https://doi.org/10.1016/j.marpol.2019.103798

69. Brasil. Decreto Federal No. 6,040 de 7 de fevereiro de 2007 [Federal Decree No. 6,040 of 7 February 2007]. Diário Oficial da União, Brasília, DF, P. 316 of 08 February 2007.

70. Brasil. Lei Federal No. 7,661 de 16 de maio de 1988 [Federal Law No. 7,661 of 16 May 1988]. Diário Oficial da União, Brasília, DF, P. 8633 of 18 May 1988.

71. Brasil. Decreto Federal No. 5,300 de 7 de dezembro de 2004 [Federal Decree No. 5,300 of 7 December 2004]. Diário Oficial da União, Brasília, DF, P. 2 of 08 December 2004.

72. Brasil. Decreto Federal No. 9,586 de 27 de novembro de 2018 [Federal Decree No. 9,586 of 27 November 2018]. Diário Oficial da União, Brasília, DF, P. 2 of 28 November 2018.

73. Brasil. Lei Federal No. 8,069 de 13 de julho de 1990 [Federal Law No. 8,069 of 13 July 1990]. Diário Oficial da União, Brasília, DF, P. 13563 of 16 July 1990. 